\title{
Aksjologiczne podstawy wsparcia społecznego
}

Człowiek jako istota społeczna nieustannie spotyka innych ludzi. W czasach, gdy pojęciem „spotkanie” określa się także kontakt za pośrednictwem portali, komunikatorów czy telefonów, spotkanie nabiera nowego znaczenia - można się „spotkać”, nie doświadczając obecności drugiego człowieka. Ksiądz Józef Tischner zwracał uwagę na głęboki wymiar ludzkich spotkań, pisząc: „Doświadczenie drugiego człowieka oznacza otwarcie dla mnie etycznego horyzontu mojego istnienia. W ramach tego horyzontu ja jako człowiek obcuję z drugim jako człowiekiem. Istotę tego obcowania stanowi pojęty egzystencjalnie dialog dobrej woli. W dialogu tym chodzi o dobro i zło, o wartość i antywartość, o winę i niewinność, o czyste i nieczyste sumienie, o jakieś ludzkie życie i o ratunek od śmierci nieludzkiej. Dobro drugiego jest sprzężone z moim dobrem, a moje dobro z dobrem drugiego" ${ }^{\text {. }}$

Spotkanie z drugim człowiekiem jest otwarciem na etyczny horyzont myślenia, którego fundament stanową wartości. Odwołanie do nich pozwala na doświadczenie drugiego jako osoby, z którą może się dokonać wymiana dóbr. Angażując się w system pomocowy, człowiek przekazuje dobro, jednocześnie je otrzymując. Nawiązanie

1 J. Tischner, Myślenie wedtug wartości, Kraków 1994, s. 387-388. 
dialogu odbywającego się w przestrzeni aksjologicznej nabiera wyjątkowego znaczenia $\mathrm{w}$ perspektywie wsparcia społecznego. Spotkanie z człowiekiem, który oczekuje na pomoc, domaga się podjęcia działań na miarę jego godności. To znaczy, że chcąc przynieść rzeczywistą ulgę, „zachować od śmierci nieludzkiej", trzeba działać w oparciu o miłość, odpowiedzialność, prawdę i inne wartości ważne dla jednostki i społeczeństwa.

Geneza działań pomocowych odwołuje się do doświadczeń ludzi, którzy pomagali innym, kierując się osobistymi wartościami i przekonaniami. Chcąc opisać i usprawnić współczesny system wsparcia, należy odwołać się do tych pierwotnych źródeł i w ich perspektywie zobaczyć istotę pomocy udzielanej drugiemu człowiekowi. W tym celu zostaną przedstawione wybrane cztery obszary wsparcia: praca socjalna, wsparcie pedagogiczne, medyczne oraz prawne. Na ich przykładzie zostanie dokonana analiza aksjologicznych podstaw działań społecznych. Na początku warto przedstawić zarys wsparcia społecznego i jego związek z wartościami.

\section{Wsparcie społeczne}

Wsparcie społeczne (ang. social support), podobnie jak wiele innych pojęć z zakresu działań społecznych, ma korzenie pragmatyczne, a kwerenda literatury przedmiotu prowadzi do stwierdzenia, że nie ma ono jednoznacznego opracowania terminologicznego. Część definicji opiera się na szerokim i pragmatycznym ujęciu zagadnienia i traktuje je jako pomoc dostępną dla jednostki w sytuacjach trudnych bądź też jako konsekwencję przynależności człowieka do sieci społecznych. Odmienne spojrzenie prezentują koncepcje, które kładą nacisk na procesualny bądź behawioralny aspekt wsparcia, utożsamiając je z zachowaniami pomocowymi lub zaspokajaniem potrzeb $\mathrm{w}$ trudnych 
sytuacjach. Działania pomocowe są gwarantowane przez osoby znaczące i grupy odniesienia ${ }^{2}$. W takim ujęciu wsparcie społeczne można zdefiniować jako „pomoc emocjonalną, informacyjną lub materialną, udzielaną jednostce przez ludzi, z którymi jest ona powiązana”3.

Na kanwie tych założeń można wyróżnić klasyczne kategorie wsparcia:

- wsparcie strukturalne i funkcjonalne,

- źródła wsparcia społecznego,

- rodzaje wsparcia,

- wsparcie otrzymywane i spostrzegane,

- potrzebę i mobilizację wsparcia ${ }^{4}$.

Potrzeba wsparcia pojawia się najczęściej w wyniku wystąpienia sytuacji stresowej. Wsparcie społeczne może przyczynić się do zmniejszenia czynnika stresowego lub go zniwelować. Dzieje się tak wówczas, gdy dochodzi do przewartościowania sytuacji trudnej na pozytywną. Wsparcie może także pomóc w zachowaniu dobrego stanu fizycznego i psychicznego, np. przez zastosowanie mechanizmów pozwalających na odreagowanie napięcia związanego ze stresem ${ }^{5}$.

Spośród wymienionych wymiarów wsparcia warto zatrzymać się nad podziałem na wsparcie strukturalne i funkcjonalne. Według Heleny Sęk i Romana Cieślaka strukturalny charakter wsparcia odnosi się do obiektywnie istniejących sieci społecznych, które odróżniają się od innych sieci po-

2 H. Sęk, R. Cieślak, Wsparcie społeczne - sposoby definiowania, rodzaje i źródła wsparcia, wybrane koncepcje teoretyczne, [w:] Wsparcie społeczne, stres $i$ zdrowie, red. H. Sęk, R. Cieślak, Warszawa 2004, s. 14.

3 D. T. Kenrick, S. L. Neuberg, R. B. Cialdini, Psychologia społeczna. Rozwiane tajemnice, Gdańsk 2002, s. 347.

$4 \quad$ H. Sęk, R. Cieślak, Wsparcie..., dz. cyt., s. 14.

5 Por. W. Badura-Madej, Podstawowe pojęcia teorii kryzysu i interwencji kryzysowej, [w:] Wybrane zagadnienia interwencji kryzysowej. Poradnik dla pracowników socjalnych, red. W. Badura-Madej, Warszawa 1996, s. 27. 
przez fakt istnienia więzi, na bazie których mogą one pełnić funkcję pomocną wobec osób osadzonych w sieci ${ }^{6}$. Często sieci społecznego wsparcia tworzą środowiska naturalne. Są one szybsze i skuteczniejsze w działaniu niż środowiska instytucjonalne, w których relacje ludzkie mają charakter zamierzony ${ }^{7}$.

W strukturalnym ujęciu zagadnienia wsparcia społecznego ważną rolę odgrywają cechy, którymi winna się charakteryzować sieć. Jedną z nich jest dostępność, która odgrywa szczególną rolę w przypadku osób samotnych i starszych. Dla nich łatwość nawiązania kontaktu pomocowego stanowi podstawowe kryterium wydolności systemu wsparcia. Kolejnymi ważnymi cechami są homogeniczność i heterogeniczność sieci, czyli podobieństwo i zróżnicowanie położenia życiowego osób. Podobieństwo wzmacnia skuteczność wsparcia w przypadku silnych stresów, doświadczanych przez grupy społeczne, np. wdowy czy dzieci alkoholików ${ }^{8}$. Cechą charakteryzującą sieć wsparcia jest także altruizm, odzwierciedlający poziom prospołeczności. Jest ona nastawieniem jednostki na pomaganie, bezinteresowność czy zaangażowanie dla dobra innych.

Rozważając kolejne kategorie wsparcia, można wyróżnić wsparcie spostrzegane i rzeczywiście otrzymane. Pierwsze z nich ma charakter prospektywny, wybiegający w przyszłość. Drugie jest spojrzeniem retrospektywnym, pozwalającym na ocenę opartą na obiektywnych faktach. Spostrzegane i otrzymywane wsparcie zależy m.in. od sytuacji trudnej, potrzeb odczuwanych przez osoby i podstawowych cech sieci.

Obiektywnie istniejące sieci wsparcia mają swoje źródła, którymi są osoby i grupy społeczne. Stanowią one zasoby

Por. H. Sęk, R. Cieślak, Wsparcie..., dz. cyt., s. 14.

Por. M. Winiarski, Wsparcie społeczne, [w:] Encyklopedia pedagogiczna XXI wieku, red. T. Pilch, t. VII, Warszawa 2008, s. 273.

8 Por. H. Sęk, R. Cieślak, Wsparcie..., dz. cyt., s. 15. 
wsparcia społecznego, których dostarczają inni ludzie komunikujący danej osobie bądź grupie bliskość emocjonalną, a także gotowość pomocy materialnej czy informacyjnej. Każdy, kto wchodzi w znaczące relacje społeczne, może stanowić część sieci wsparcia: „Gdy ludzie mają się do kogo zwrócić, potrafią lepiej radzić sobie ze stresorami związanymi z pracą, bezrobociem, problemami małżeńskimi oraz poważnymi chorobami, a także codziennymi kłopotami życiowymi"

Zasoby wsparcia społecznego mogą zostać wykorzystane w sytuacji stresowej, np. w przypadku terminalnej choroby dziecka. Dla rodziców opiekujących się dzieckiem bardzo ważnego znaczenia nabiera wsparcie otrzymywane od członków rodziny i pracowników hospicjum, gdyż poszukują oni „możliwości psychicznego oparcia się w kimś bliskim, z możliwością wygadania się i przewentylowania uczuć, zmniejszenia poczucia osamotnienia w nieszczęściu, prowadzącego do zmniejszenia napięcia, które towarzyszy zwykle opiekunom"10. Dzięki temu poziom stresu może się znacznie obniżyć.

Nieco inne atrybuty wsparcia ukazuje ujęcie funkcjonalne. Jest ono rodzajem „interakcji społecznej, która zostaje podjęta przez jednego lub obu uczestników sytuacji problemowej, trudnej, stresowej, krytycznej"11. Takie spojrzenie na wsparcie podkreśla „relacyjny charakter wsparcia społecznego wyrażający się m.in. w konsekwencjach jego udzielania oraz otrzymywania, ocenie, spostrzeganej dostępności i adekwatności do potrzeb oraz problemów

$9 \quad$ R. J. Gerrig, P. G. Zimbardo, Psychologia $i$ życie. Wydanie nowe, Warszawa 2011, s. 412.

10 K. de Walden-Gałuszko, Problemy psychiczne, duchowe $i$ etyczne, [w:] Pielegniarstwo w opiece hospicyjnej, red. K. de Walden-Gałuszko, A. Kaptacz, Warszawa 2008, s. 205.

11 H. Sęk, Wprowadzenie do psychologii klinicznej, Warszawa 2007, s. 268. 
osoby doświadczającej sytuacji trudnych"12. Silna więź, nasycona altruizmem i wzajemnością, generuje i wzmacnia poczucie powinności. Jest ona nawiązywana w celu udzielenia uczestnikom pomocy w rozwiązaniu problemu, przezwyciężeniu trudności, reorganizacji zakłóconej relacji $\mathrm{z}$ otoczeniem czy podtrzymaniu emocjonalnemu ${ }^{13}$. By ów warunek mógł zaistnieć, konieczne jest istnienie sieci społecznych, z którymi jednostka jest powiązana i do których ma dostęp.

Wsparcie funkcjonalne może być rozumiane jako interakcja, ale także jako proces wymiany. W toku interakcji zachodzi bowiem wymiana emocji, informacji czy instrumentów działania. Warunkiem skuteczności tej wymiany jest kompatybilność między rodzajem i wielkością udzielanego wsparcia i potrzebami odbiorców. Interakcja warunkująca wymianę zmniejsza stres, a także daje poczucie przynależności i bezpieczeństwa ${ }^{14}$.

W zależności od tego, co jest treścią wymiany społecznej w toku interakcji, wyodrębnia się różne rodzaje wsparcia:

- wsparcie emocjonalne, polegające na przekazywaniu emocji podtrzymujących, uspokajających, wyrażających troskę, umożliwiających uwolnienie się od napięć i wzmacniających nadzieję;

- wsparcie informacyjne, czyli wymiana takich informacji, które sprzyjają lepszemu zrozumieniu sytuacji i problemu, dzielenie się doświadczeniami;

- wsparcie instrumentalne, czyli instruktaż dotyczący konkretnych sposobów postępowania, modelowanie skutecznych zachowań zaradczych;

12 L. Marszałek, Systemy wsparcia społecznego w rehabilitacji osób niepetnosprawnych, „Seminare” 2009 t. 26, s. 203.

13 Por. E. Bielecka, Tradycyjne i innowacyjne formy interwencji spotecznej, [w:] Zagrożona młodość. Innowacyjne formy interwencji społecznej, red. E. Bielecka, Warszawa 2010, s. 11.

14 Por. H. Sęk, Wprowadzenie..., dz. cyt., s. 268. 
- wsparcie rzeczowe, czyli świadczona pomoc materialna lub bezpośrednie, fizyczne działanie na rzecz osób potrzebujących;

- wsparcie duchowe, świadczone na przykład w opiece hospicyjnej, gdzie praca wymaga odniesień do sfery ducha ${ }^{15}$.

Każdy rodzaj stosowanego wsparcia winien spełniać kryterium trafności, które określa zgodność treściową i ilościową wsparcia, które jest potrzebne, i wsparcia, które się otrzymuje. Warunkuje ona skuteczność podejmowanych działań pomocowych ${ }^{16}$. Jeśli działania te tworzą spójną i wydolną sieć wsparcia społecznego, opartą na wzajemnej współpracy podmiotów, realizacja zadań pomocowych przebiega w sposób prawidłowy ${ }^{17}$.

Wsparcie społeczne ma szeroki zakres znaczeniowy, o czym świadczy wielość występujących kategorii służących do opisania omawianego pojęcia. W ich świetle wsparcie jawi się jako działanie, które jest wielopoziomowe. U podstaw tego zaangażowania znajdują się wartości, dzięki którym działania pomocowe, jak i ich postrzeganie oraz przyjmowanie mają odniesienie aksjologiczne. Stanowi ono fundament dla wielu działań pomocowych, świadczonych przez instytucje oraz społeczności naturalne.

\section{Aksjologiczny kontekst wsparcia społecznego}

Pomoc drugiemu człowiekowi jest jedną z postaw prospołecznych cieszących się powszechnym uznaniem. Cho-

15 Por. H. Sęk, R. Cieślak, Wsparcie..., dz. cyt., s. 18.

16 Por. D. Włodarczyk, Wsparcie społeczne a radzenie sobie ze stresem u chorych po zawale serca, ,Przegląd Psychologiczny” 1999 t. 42 nr 4, s. 95.

17 Por. D. Kubacka-Jasiecka, Interwencja kryzysowa. Pomoc w kryzysach psychologicznych, Warszawa 2010, s. 520. 
ciaż działania pomocowe przybierają bardzo różnorodne formy, można wyodrębnić dwa podstawowe sposoby myślenia o pomaganiu. Są one związane z dwoma modelami udzielania pomocy, z których pierwszy, dominujący w życiu codziennym, określa pomaganie jako dawanie osobie tego, czego jej brak. Drugi model związany jest z podstawową ideą, według której pomagający ma na celu zwiększenie u osoby przyjmującej pomoc zdolności do pomagania samej sobie ${ }^{18}$. Różne kierunki pomocowe nie są jedynie wynikiem zastosowania różnych metodyk pracy z klientem. Rozróżnienie to ma swe źródło także w różnych założeniach aksjologicznych przyjętych przez świadczących pomoc, a te rodzą zobowiązania etyczne. Bez odniesienia aksjologicznego i związanego z nim myślenia etycznego powstają normy postępowania, które niczym instrukcje funkcjonowania maszyn mają zapewnić ład w społeczeństwie. Nie spełniają jednak one swego zasadniczego celu - nie służą dobru człowieka.

By działanie pomocowe było racjonalne i przynosiło pożądane efekty, musi sięgać do założeń teoretycznych. W przypadku życia społecznego wiedza o wartościach jest kluczowa, gdyż w nim człowiek „pełni rolę, która ze względu na podjęte zobowiązania i treści realizowanych działań ma służyć dobru jednostki lub określonym zbiorowościom, czyli w tych sferach naszego życia, gdzie praca zawodowa staje się misją społeczną o dużych walorach aksjologicznych"19.

Wartości mogą być różnie rozpatrywane przez poszczególne dyscypliny naukowe. Dla użyteczności nauk społecz-

18 Por. A. Kuczkowska-Krukowska, Istota wspomagania społecznego - przeglad wybranych stanowisk, „Wychowanie na co Dzień” 2006 nr 6, s. 16.

19 R. Bera, Aksjologiczne aspekty pracy socjalnej, [w:] Przestrzenie dziatania $w$ pracy socjalnej $w$ wymiarze etyczno-prakseologicznym, red. M. Czechowska-Bieluga, A. Kanios, L. Adamowska, Kraków 2010, s. 28. 
nych szczególnie istotne wydaje się ujęcie z perspektywy filozofii, psychologii, socjologii, antropologii kulturowej czy pedagogiki. Wydaje się, że dla dalszych rozważań zasadne jest zwrócenie uwagi na rozumienie wartości w ujęciu filozoficznym. W czasach, gdy rola filozofii w życiu społecznym nieustannie słabnie, warto dowartościować tę niezmiernie ważną perspektywę.

Wartość jest podstawową kategorią aksjologii. Według Jana Galarowicza oznacza wszystko, co jest cenne, ważne, doniosłe, a w szczególnym znaczeniu ważne samo w sobie $^{20}$. Spośród wielu istniejących podziałów wartości warto przytoczyć jeden z nich, odnoszący się do życia jednostki i społeczeństwa, rozróżniający wartości osobowe i społeczne $^{21}$. Wartości osobowe zawierają w sobie wartości ostateczne oraz wartości związane z życiem codziennym. Pierwsze z nich stoją na czele hierarchii wartości, stanowią klucz do ich zrozumienia i nadają sens ludzkim działaniom, w których następuje realizacja wartości z niższych stopni hierarchii. Wartości społeczne są obecne w życiu społeczeństw, nadają kierunek i sens porządku społecznego, który trzeba „rozwijać, opierając na prawdzie, budować w sprawiedliwości, ożywiać miłością; w wolności zaś powinno się odnajdywać coraz pełniej ludzką równowagę"22. Prawda, sprawiedliwość, wolność i miłość stanowią podstawowe prawdy, na których winno się opierać funkcjonowanie społeczeństw, w tym także podejmowane przez nie działania.

Wartości określają relację człowiek - człowiek, człowiek - grupa społeczna, człowiek - środowisko społecz$\mathrm{ne}^{23}$. Dzięki wartościom relacje te mogą się właściwie roz-

\footnotetext{
20 Por. J. Galarowicz, Nowy elementarz etyczny, Kraków 2011, s. 269.

21 Por. K. Chałas, Wychowanie ku wartościom. Elementy teorii i prakty$k i$, t. I, Lublin-Kielce 2006, s. 25.

22 Sobór Watykański II, konst. Gaudium et spes, 26.

23 Por. K. Chałas, Wychowanie..., dz. cyt., s. 32.
} 
wijać i wnosić dobro w życie jednostek i społeczeństw. W tym kontekście można przyjąć, że wartości są źródłem dynamizmu społeczeństwa dążącego do zmian, gdyż inspirują znaczące inicjatywy społeczne. Jednocześnie ukierunkowują i legitymizują działania jednostek i grup, pełniąc zarazem funkcję sankcji społecznej. W razie potrzeby wartości interweniują w strukturę systemu działania jednostki i grupy. Dostarczają im treść ideologiczną, a zarazem stanowią czynnik podtrzymania przyjętych zasad. Stanowią również podstawę sieci relacji między jednostkami lub grupami i je integrują ${ }^{24}$.

Społeczna rola wartości wyznacza principia działań społecznych, w tym także świadczenia pomocy jednostkom i grupom. Odniesienie do wartości w podejmowaniu działań pomocowych bierze się z wartości spotkania z drugim człowiekiem, doświadczenia jego obecności i potrzeb. Ksiądz Tischner pisał: „Doświadczenie drugiego człowieka, jeśli się je uchwyci w jego nie zafałszowanym przez technikę rdzeniu, jest doświadczeniem par excellence etycznym. [...] W nim znajdują swój fundament podstawowe wartości etyczne: prawda, sprawiedliwość, wierność itd. W nim kryje się podstawa obiektywizmu dla naszych zobowiązań etycznych. Tu leży źródło prawdziwej odpowiedzialności za świat zewnętrzny. Jeśli ktoś zezwoli na to, by stępiła się w nim wrażliwość na drugiego człowieka, cała jego moralność i całe myślenie etyczne zawiśnie w próżni”25.

Godność człowieka znajduje się w centrum rozważanych wartości społecznych, gdyż to jego dobra bronią normy moralne. Godność osoby ludzkiej uzasadnia istnienie normy personalistycznej. W pozytywnym znaczeniu może

24 Por. K. Ryczan, Wychowanie ku wartościom, [w:] Na przełomie stuleci. Naród - Kościót - państwo w XIX i XX wieku, red. M. Piotrowski, Lublin 1997, s. 555-556.

25 J. Tischner, Myślenie..., dz. cyt., s. 385. 
być ona ujęta jako czyn afirmacji osoby ludzkiej, stanowiący adekwatną odpowiedź na jej wartośćc ${ }^{26}$. Negatywne spojrzenie na normę personalistyczną określa działania, których podjęcie byłoby zaprzeczeniem godności osoby.

Wrażliwość na drugiego człowieka jest otwarciem na jego godność, niezaprzeczalną wartość. Wszelkie działania świadczone drugiemu winny czerpać swą inspirację z tego źródła: „Oto widzę na twarzy drugiego życzliwy uśmiech, wtedy wiem: tr zeba mu odpowiedzieć czymś podobnym. Oto widzę rysujący się ból i również wiem: tr zeba zapytać, co się stało. Jakiś ranny leży obok drogi, znów wiem: trzeba coś zrobić" 27 .

Powinność rodząca się z doświadczenia drugiego człowieka i uszanowania jego godności przeradza się w etyczne zobowiązanie: tr zeba. Powinność jest zatem obszarem etyki. Słowo „etyka” wywodzi się z greckiego terminu ethos i oznacza „zwyczaj, obyczaj”, a także „usposobienie, zachowanie się"28. Rozważana w kontekście społecznym etyka opiera się na istnieniu dwóch podmiotów moralnego działania: osoby i społeczności. Z relacji pomiędzy nimi wypływają normy etyczno-społeczne, które kształtują się na płaszczyźnie sprawiedliwości i miłości ${ }^{29}$. O ile norma sprawiedliwości reguluje wzajemne zobowiązania między podmiotami społecznymi, miłość głosi ideę wznoszenia się na możliwie najwyższy poziom czynienia dobra, z zachowaniem norm sprawiedliwości. Na gruncie tych założeń powstała etyka zawodowa, która obejmuje również działania pomocowe świadczone potrzebującym. W ten sposób osoba ludzka staje się elementem łączącym aksjologię i etykę z działaniami pomocowymi.

\footnotetext{
26 Por. J. Galarowicz, Nowy elementarz..., dz. cyt., s. 87-88.

27 J. Tischner, Myślenie..., dz. cyt., s. 386.

28 T. Ślipko, Etyka, [w:] Słownik społeczny, red. B. Szlachta, Kraków 2004, s. 248.

29 Por. tamże, s. 269 (248-279).
} 
W celu zaprezentowania związku aksjologii z działaniami pomocowymi zostanie przedstawionych kilka wybranych obszarów tej pomocy: praca socjalna, pomoc medyczna, pedagogiczna i prawna. Warto podkreślić, iż „każdy rodzaj pomocy - merytorycznie odmienny - wymaga innego przygotowania przez udzielających pomocy [...]. Wyodrębnione rodzaje pomocy i wyraźnie zdefiniowane kompetencje, potrzebne niosącym pomoc, pozwalają na ocenę profesjonalizmu ich pracy i umożliwiają dobór wskaźników niezbędnych do oszacowania poziomu owego profesjonalizmu"30. Dają także możliwość określenia wartości i norm etycznych, których przestrzeganie jest wyrazem kompetencji moralnych osób udzielających pomocy. Zwrócenie uwagi na etyczne odniesienia wymienionych rodzajów wsparcia pozwoli na pełniejsze przedstawienie omawianego zagadnienia.

\section{Wartości w pracy socjalnej}

Praca socjalna ma na celu zapewnienie podstawowych warunków życia tym, którzy są ich pozbawieni; zaspokajanie potrzeb, które nie mogą być zaspokojone samodzielnie lub w ramach innych instytucji; minimalizowanie negatywnego wpływu tych czynników, które nie mogą być zmienione lub usunięte oraz osiągnięcie bardziej satysfakcjonującego poziomu i jakości życia.

Wartości pełnią szczególnie ważną rolę $\mathrm{w}$ pracy socjalnej, gdyż działalność ta wymaga odwołania nie tylko do wiedzy i umiejętności, ale również do podstawowych prawd $^{31}$. Wśród wartości, które w praktyce pomocy socjalnej winny znaleźć właściwe sobie miejsce, można wyróż-

30 B. Hajduk, E. Hajduk, O rodzajach pomocy, Kraków 2006, s. 23-24.

31 Por. M. Czechowska-Bieluga, Preferencja wartości a rozwój (wybrane zagadnienia), „Praca Socjalna” 2007 nr 2, s. 9. 
nić: poszanowanie godności człowieka, odpowiedzialność, miłość bliźniego, miłosierdzie sprawiedliwość, uczciwość, prawdomówność, sumienność. Do standardów moralnych można również zaliczyć: szacunek, lojalność, życzliwość, mądre rozsądzanie, wielkoduszność czy solidarnośćc ${ }^{32}$. Każda z wymienionych wartości jest na tyle ważna, że należałoby ją szczegółowo przeanalizować. Ponieważ nie sposób w krótkim opracowaniu choćby pokrótce opisać każdą z nich, trzeba poprzestać na wybranych. Na szczególną uwagę zasługuje idea godności człowieka, gdyż stanowi ona fundament powstania i rozwoju pracy socjalnej ${ }^{33}$. Wartością, która bezpośrednio wynika z afirmacji godności osoby ludzkiej, jest odpowiedzialność. Analiza pola znaczeniowego tych dwóch wartości będzie egzemplifikacją pokazującą ich znaczenie dla pracy socjalnej.

Godność zawiera w sobie wielkość, wartość i wyjątkowość osoby: „Człowiek jako osoba stanowi najwyższą wartość w świecie stworzonym. Stąd godność określa wielką wartość człowieka, nieporównywalną z czym innym. Rzecz w tym, by tej wartości człowiek był świadomy i ją odczuwał" ${ }^{34}$. U podstaw działań mających za cel afirmację oraz rozwój godności człowieka stoją założenia antropologii judeochrześcijańskiej ${ }^{35}$. Warto również docenić wkład humanizmu, który pozbawiony redukcjonistycznego znaczenia, podkreśla godność osoby ludzkiej i wskazuje możliwości jej rozwoju. Ważne jest, by w podejmowaniu działań na rzecz godności człowieka nie zatracić duchowego wymiaru ludzkiej egzystencji, gdyż współczesny człowiek coraz częściej boryka się nie tylko z nędzą materialną, ale również duchową. Stąd rodzi się postulat „wchodzenia

32 Por. M. Kluz, O realizacje wartości moralnych $w$ działaniu pracowników socjalnych, „Praca Socjalna” 2012 nr 3, s. 27.

33 Por. tamże.

$34 \quad$ K. Chałas, Wychowanie..., dz. cyt., s. 108.

35 Por. C. D. Garvin, B. A. Seabury, Działania interpersonalne w pracy socjalnej. Procesy i procedury, tłum. J. Banasiak, Warszawa 1996, s. 58. 
w relację z drugim człowiekiem na różnych płaszczyznach: społecznej, psychologicznej, kulturowej, instytucjonalnej. Można jednak wskazać także jej dużo głębszy wymiar, dotyczy ona również rzeczywistości duchowej, więzi i wartości duchowych. Jest ona spotkaniem i dialogiem osób, które ma miejsce w przestrzeni, w której objawiają się wartości niematerialne, duchowe" ${ }^{36}$. Troska o wartości duchowe stanowi więc postulat, który winien być realizowany w trakcie działań pomocowych.

Etyczne konsekwencje przyjęcia założeń antropologicznych wyrażają się w normatywnym ujęciu podstaw pracy socjalnej. Zostały one zawarte m.in. w Kodeksie etycznym Polskiego Towarzystwa Pracowników Socjalnych. U jego założeń tkwi idea poszanowania godności człowieka i jej obrony. W oparciu o to założenie kodeks stwierdza, że „pracownik socjalny zobowiązany jest do poszanowania godności klienta" ${ }^{37}$. Owo poszanowanie winno się wyrażać nie tylko poprzez akceptację założeń teoretycznych aksjologii, ale także poprzez podejmowanie działań służących temu celowi.

Kodeks etyczny jest podstawą rozstrzygania dylematów, które na co dzień towarzyszą pracownikom socjalnym. Spośród dylematów etycznych można wymienić:

- niepokój, że zaangażowanie w problemy innych może zburzyć wewnętrzny spokój osoby pomagającej, przy jednoczesnym poczuciu obowiązku pomagania;

- potrzebę posiadania moralnego argumentu pozwalającego czuć się dobrym, przy jednoczesnych wątpliwościach co do motywacji podejmowanych działań;

- radość z okazanego zaufania przy jednoczesnej obawie, czy wystarczy sił do sprostania oczekiwaniom;

36 T. Biernat, Duchowy wymiar pracy socjalnej. Potencjat wiary, nadziei i miłości, „Praca Socjalna” 2011 nr 6, s. 4.

37 Kodeks etyczny Polskiego Towarzystwa Pracowników Socjalnych (1994), rozdz. II, www.mgopsmiroslawiec.bipstrona.pl (13.07.2014). 
- odczuwanie niechęci wobec osoby wspomaganej przy jednoczesnej konieczności podjęcia wobec niej interwencji i pokonania niechęci;

- niepewność co do rzetelności diagnozy potrzeb osoby wspomaganej przy jednoczesnym niepokoju związanym z możliwością naruszenia granic oczekiwanej pomocy podczas dokładniejszej diagnozy;

- konieczność określenia granicy wspomagania jednej osoby, gdy pomija się dobro jej bliskich;

- wybór właściwej drogi działania, która nie naruszy wartości własnych i wartości wspomaganego ${ }^{38}$.

Odpowiedzi na pytania formułowane na podstawie przytoczonych dylematów można odnaleźć, odwołując się do norm etycznych opartych na trwałych wartościach. Zostały one zawarte w zasadach etyki zawodowej pracownika socjalnego. Etyka zawodowa stanowi filar pracy socjalnej, która wyrasta z podstawowych wartości charakterystycznych dla danego społeczeństwa. Opiera się ona na zależności pomiędzy formułą określającą dane społeczeństwo, środkami realizującymi jego cele oraz osobami potrzebującymi wsparcia. Stąd według Marty Łuczyńskiej pracownik socjalny jest z jednej strony „reprezentantem instytucji, która w praktyce ma za zadanie realizować postulaty równości i sprawiedliwości społecznej, odpowiedzialności i powinności państwa demokratycznego wobec swoich obywateli. Z drugiej - jego praktyka profesjonalna to praca $\mathrm{z}$ drugim człowiekiem, słabym, niezaradnym, biednym, chorym, samotnym to również konieczność respektowania jego praw do poszanowania godności, wolności, potrzeby samostanowienia" ${ }^{39}$.

Trudności, które pojawiają się na styku wymienionych podmiotów społecznych i reprezentowanych przez

38 Por. M. Łuczyńska, O odpowiedzialności etycznej pracownika socjalnego, [w:] T. Kaźmierczak, M. Łuczyńska, Wprowadzenie do pomocy społecznej, Katowice 1998, s. 102-103.

39 Tamże, s. 97. 
nie rzeczywistości, wymagają od pracowników socjalnych szczególnych predyspozycji moralnych umożliwiających realizację założonych postulatów. Warto podkreślić, iż realizacji postulatów etycznych towarzyszy „napięcie emocjonalne, wywołane w dużej mierze rozbieżnością między oczekiwaniami beneficjentów a realną możliwością ich zaspokojenia" ${ }^{40}$. Napięcie to może prowadzić do frustracji, rozczarowania, a w konsekwencji do wypalenia. Przeciwdziałanie tym zjawiskom winno mieć wyraźne odniesienie aksjologiczne, gdyż oddziaływanie wartości ma charakter dwustronny - stanowią one podstawę określania celów działań pomocowych, a jednocześnie uzdalniają pracowników do pokonywania trudności zawodowych. Poszanowanie godności drugiego człowieka staje się możliwe jedynie pod warunkiem afirmacji przez pracownika socjalnego własnej godności.

Wartości wpływają na rozwój osobowościowy człowieka i sprawiają, że można zapobiec syndromowi wypalenia zawodowego $^{41}$. Istotną rolę w jego pojawieniu się odgrywa współczynnik depersonalizacji, określający poczucie bezduszności, bezosobowości i obniżenie wrażliwości wobec innych. W oparciu o badania empiryczne dotyczące poziomu depersonalizacji wśród pracowników sektora wsparcia społecznego można przyjąć, że jego poziom wśród badanych nie był na tyle wysoki, by uniemożliwić realizację postulatu afirmacji godności osoby ludzkiej ${ }^{42}$. Napawa to nadzieją, że przeważająca większość badanych pracowników cieszy się adekwatną oceną samych siebie oraz otaczających

40 E. Lichnerowicz, Praca socjalna $w$ organizacjach pozarzadowych $i$ instytucjach publicznych - perspektywa pracownika socjalnego, „Trzeci Sektor” numer specjalny 2012/2013, s. 87.

41 Por. M. Czechowska-Bieluga, Preferencja..., dz. cyt., s. 9.

42 Por. A. Kanios, M. Czechowska-Bieluga, Preferencyjne wartości a wypalenie zawodowe osób profesjonalnie świadczacych pomoc, „Praca Socjalna" $2010 \mathrm{nr}$ 6, s. 61-62. 
osób i nie zatraca perspektywy personalistycznej w podejmowanych działaniach.

Ważną cechą, która winna wyróżniać pracownika socjalnego, jest odpowiedzialność, będąca konsekwencją afirmacji godności drugiego człowieka. Odpowiedzialność pracownika socjalnego w jego pracy zawodowej wyraża się w odpowiedzialnym działaniu i ponoszeniu konsekwencji za podejmowane decyzje, klienta, efekty pracy. Obszary odpowiedzialności nabierają szczególnego znaczenia poprzez odniesienie do sytuacji, w której osoba przyjmująca pomoc jest słabsza, bezradna i zagubiona: „Warto zaznaczyć, że im wyższy poziom bezradności klienta, tym wyższy poziom odpowiedzialności pracownika socjalnego" ${ }^{\prime 3}$. Niemożliwe jest zupełne zrzeczenie się niekiedy trudnego poczucia odpowiedzialności, co nie oznacza, że nie powinno się podejmować działań zmierzających do przygotowania osoby potrzebującej pomoc do partycypowania w tym poczuciu.

Na kanwie założeń dotyczących roli odpowiedzialności w pracy socjalnej można przyjąć, iż wyraża się ona w:

- samostanowieniu, czyli poszanowaniu praw klienta do określenia własnych celów i sposobów ich osiągania;

- trosce wyrażającej się w uwzględnianiu dobra innych i rozwijaniu tej umiejętności u osoby otrzymującej wsparcie;

- odpowiedzialności społecznej, polegającej na podnoszeniu społecznej sprawności tworzenia dobra i współpracy w tym względzie wszystkich podmiotów tworzących interakcje społeczne ${ }^{44}$.

Aby móc osiągnąć zadowalający poziom odpowiedzialności zawodowej, należy posiąść umiejętność rozpoznawania wartości społecznych, rozwiązywania ich konfliktów oraz odpowiedniego kształcenia kadry pracowniczej.

\footnotetext{
43 M. Łuczyńska, O odpowiedzialności..., dz. cyt, s. 99.

44 Por. C. D. Garvin, B. A. Seabury, Działania..., dz. cyt., s. 59.
} 
Konieczne jest więc kształcenie aksjologiczne, które towarzyszyłoby przyszłym pracownikom socjalnym, a także podnosiło poziom skuteczności oddziaływań. Niezbędne jest także wzmacnianie pozytywnych postaw wśród pracowników i nieustanne podnoszenie kompetencji moralnych. Podczas badań na temat rzeczywistego przestrzegania norm kodeksu etycznego przez pracowników socjalnych $65,3 \%$ osób stwierdziło, że raczej przestrzega tych zasad, a prawie jedna trzecia zadeklarowała, że bezwzględnie zawsze postępuje zgodnie z kodeksem ${ }^{45}$. Wierność zobowiązaniom etycznym, a przez to uznanym wartościom stanowi wyznacznik personalistycznego charakteru świadczonej pomocy.

\section{Aksjologiczne podstawy pomocy pedagogicznej}

Pomoc pedagogiczna jest udzielana uczniom bądź studentom i ma na celu ułatwienie radzenia sobie z problemami edukacyjnymi, osobistymi czy problemami w kontaktach społecznych z rówieśnikami, rodzicami bądź innymi członkami rodziny ${ }^{46}$. Najczęściej przyjmuje ona formę rady, zachęty, terapii, rozmowy podnoszącej samoocenę, a niekiedy może wyrażać się poprzez wsparcie materialne, np. w zakupie podręczników. Pomoc pedagogiczna nie jest zarezerwowana jedynie dla instytucji szkoły. Udzielają jej również poradnie psychologiczno-pedagogiczne czy wychowawcy pracujący w internatach.

Pomoc pedagogiczna może także przybierać formę pedagogizacji rodziców ucznia. Jest to wtedy „działalność zmierzająca do stałego wzbogacania posiadanej przez ro-

45 A. Kanios, Wokót profesjonalizmu pracowników socjalnych - analiza badawcza, „Praca Socjalna” 2012 nr 3, s. 92.

46 Por. B. Hajduk, E. Hajduk, O rodzajach..., dz. cyt., s. 31. 
dziców potocznej wiedzy pedagogicznej o elementy naukowej wiedzy o wychowaniu dzieci i młodzieży" ${ }^{\prime 7}$. Podnoszenie poziomu świadomości pedagogicznej obejmuje wiedzę oraz umiejętności wychowawcze rodziców, przez co szanse na optymalne wychowanie dziecka zostają zwiększone. Poszerzenie zakresu świadomości pedagogicznej nie polega jedynie na przekazaniu wiedzy o wychowaniu, gdyż proces ten obejmuje również przekaz wiedzy psychologicznej, medycznej, jak i moralnej, a więc umożliwia również spotkanie $\mathrm{z}$ wartościami ${ }^{48}$. Propozycje te zakładają trójpodmiotowość i partnerstwo, a jednocześnie odwołując się do podstaw aksjologicznych kształtowania osobowości, zwiększają efekty wychowawcze. Są one cennym wkładem w rozwój procesu wychowania dzieci i dorosłych.

Działania pedagogiczne mają odniesienie etyczne, a więc zawierają się w kategorii moralności. Aksjologiczna perspektywa pomocy pedagogicznej ma kilka wymiarów. Może opisywać wartości w kontekście teleologii wychowawczej, zajmować się metodyką ich wdrażania, analizować przyczyny sukcesów niepowodzeń wychowawczych czy prognozować działania służące wychowaniu ku wartościom. Interesujące zagadnienia wiążą się również z osobą wychowawcy i wartościami, które prezentuje i przekazuje. Widać tutaj wyraźne odniesienie do pojęcia etosu nauczyciela, który realizuje się między innymi poprzez postępowanie zgodne z powszechnie przyjętymi standardami moralnymi. Wskazują one na fakt, że realizacja wsparcia pedagogicznego opiera się na obiektywnie określonych

47 S. Kawula, Pedagogizacja rodziców, [w:] Encyklopedia pedagogiczna, red. W. Pomykało, Warszawa 1993, s. 581.

48 Por. G. Godawa, Nauczyciel dzieci - wychowawca rodziców. Oddziatywanie wychowawcze kompetentnego nauczyciela na sfere duchowa rodziców uczniów (na podstawie badań rodziców w krakowskich szkołach), [w:] Ewaluacja $i$ innowacje w edukacji. Kompetencje $i$ odpowiedzialność nauczyciela, red. J. Grzesiak, Kalisz-Koszalin 2010, s. 426. 
moralnych normach prawnych, pedagogicznych oraz etycznych, których przestrzeganie warunkuje odpowiedzialne potraktowanie procesu edukacyjnego ${ }^{49}$.

Struktura wartości realizowanych $\mathrm{w}$ pedagogice jest bardzo rozbudowana. Obejmuje wartości o charakterze transcendentnym, tj. powszechny imperatyw czynienia dobra i unikania zła, postawy wiary, nadziei i miłości oraz odniesienie do Boga jako Nadwartości. Obok nich można wyodrębnić wartości o cechach naturalnych. W ich strukturę wchodzą:

- wartości wewnętrzne, do których można zaliczyć wartości związane z osobowością danego człowieka, jego wszechstronnym rozwojem i czynami społecznymi;

- wartości społeczne, które można zgrupować wokół wartości związanych z rodziną i innymi formami samorealizacji, współżyciem i współpracą z innymi ludźmi;

- umiejętności pracy i zawodu ${ }^{50}$.

Wartości społeczne stanowią fundament porozumienia społecznego i sprawiają, że grupa społeczna może razem żyć, komunikować się i podejmować działania. Do tych wartości należą m.in.: ojczyzna, naród, Kościół, patriotyzm, niepodległość, godność człowieka, wolność, pokój, tolerancja, demokracja czy solidarnośćc1. Wydaje się, że głębsze spojrzenie na tolerancję jako na wartość podstawową w działaniach pomocowych o charakterze wychowawczym pozwala na ukazanie aksjologicznego wymiaru tego wsparcia.

Krystyna Chałas pisała: „U podstaw tolerancji znajduje się człowiek, jego działania, poglądy, opinie, sposób życia. Pod jednym warunkiem, że nie stanowią one nośników zła.

49 Por. G. Godawa, Odpowiedzialność nauczyciela za niewypowiedziane stowa, czyli o zaniedbaniu pedagogicznym w szkole, „Studia Socialia Cracoviensia" 2010 nr 3, s. 95.

50 Por. J. Homplewicz, Etyka pedagogiczna, Kraków 2000, s. 156.

51 Por. K. Chałas, Wychowanie..., dz. cyt., s. 64. 
Tolerancja ogniskuje krytyczną ocenę powyższych elementów oraz zgodę na nie mimo braku aprobaty z naszej strony. Poszanowanie godności drugiego człowieka i szacunek dla niego zobowiązuje do tolerancji go jako osoby"52. Nie sposób zlekceważyć postulatu tolerancji człowieka, osadzonej na jego godności. Różnice w poglądach nie mogą stanowić przeszkody w podejmowaniu działań, które mają na celu pomoc w trudnych sytuacjach życiowych.

Idea poszanowania godności drugiego człowieka, o której była już mowa, nabiera szczególnego charakteru w kontekście pomocy pedagogicznej. Jeśli ma ona stanowić trafny i skuteczny środek wsparcia, winna szanować wolność drugiego człowieka. Spojrzenie na wolność człowieka i tolerancję ma dzisiaj wiele znaczeń. Według Ewa Podrez można przyjąć, iż „tolerancji przysługują dwa podstawowe znaczenia: pierwsze z nich to pobłażliwość, okazywanie cierpliwości i wyrozumiałości; drugie to afirmacja lub popieranie cudzej odmienności, a także szacunek dla jego autonomii i wolności" ${ }^{53}$. Wydaje się, że takie ujęcie pokazuje, iż tolerancja jest sama w sobie wartością, która uzasadnia swą rację bytu godnością człowieka. Jednocześnie broni wartości, które są zagrożone w życiu społecznym i wychowaniu.

Pierwsze, negatywne znaczenie tolerancji nawiązuje do źródłosłowu łacińskiego (łac. tolerantio - znoszenie, cierpliwość, wytrzymywanie, cierpienie) i wskazuje na wysiłek konieczny do jej zastosowania. Owo „znoszenie” może być wyrazem miłości wobec kogoś, kto ma odmienne poglądy, i wypływa z szacunku i zdrowego rozsądku. Pozytywne ujęcie tolerancji akcentuje potrzebę akceptacji i partnerstwa. Spojrzenie na drugiego człowieka bez stereotypów

Tamże, s. 201.

53 E. Podrez, Tolerancja - problemy i dylematy nie tylko moralnej natury, [w:] Tolerancja i wielokulturowość. Wyzwania XXI wieku, red. A. Borowiak, P. Szarota, Warszawa 2004, s. 16. 
i negatywnych obciążeń kulturowych pozwala na dostrzeżenie elementów wspólnych oraz właściwe potraktowanie tego, co odmienne. Dzięki temu tolerancja nie prowadzi do relatywizacji wartości i postaw moralnych, co stanowi bardzo istotny aksjomat pedagogiczny. Afirmacja i otwarcie na drugiego człowieka nie wyklucza więc zachowania poczucia tożsamości, odrębności i niezależności.

Powyższe założenia, realizowane w obszarze wsparcia pedagogicznego, napotykają wiele trudności. Należy do nich błędne rozumienie tolerancji, które sprowadza się do rozumienia jej w sensie obojętności bądź aprobaty wszystkiego, co otacza człowieka. Przejawem tej postawy może być milcząca akceptacja kłamstwa, nienawiści, korupcji, wulgaryzmów, nieuczciwości, a w konsekwencji koloru skóry, obyczajów czy wyznania religijnego. Z kolei tolerancja bezkrytyczna, czerpiąca swą uniformizację z globalizmu, zatraca podstawowe różnice, nie uznaje obiektywnie istniejących wartości i wprowadza myślenie oparte na subiektywizmie.

Obszary konfliktów w działaniach pomocowych mogą obejmować dylematy pomiędzy utrudnieniami w realizacji postulatu ustalonego programu a własnymi przekonaniami światopoglądowymi i postawą ideową. Mogą się one ukonkretniać w dylematach dotykających granic tolerancji:

- między zasadą sprawiedliwości a zasadą pobudzania do większego wysiłku;

- między zasadą osobistego kontaktu z wychowankiem a zasadą utrzymania niezbędnego dystansu;

- między troską o aktualne dobro wychowanka a troską o jego przyszłe losy ${ }^{54}$.

Powyższe dylematy mogą się wiązać z brakiem wystarczających kompetencji moralnych pedagoga. Chodzi

54 Por. J. Zowczak, Etos nauczycieli w warunkach polskiej transformacji, Warszawa 2008, s. 159. 
o zdolność prowadzenia refleksji moralnej ${ }^{55}$. Kompetencje odwołują się do sfery moralnej postaw wychowawcy wobec samego siebie, jak i osób powierzonych jego pieczy. To „powierzenie” rodzi etyczną odpowiedzialność za właściwe kształtowanie osobowości wychowanków ${ }^{56}$. Normy określające etyczne postawy pedagoga zostały opracowane w kodeksach etyki nauczyciela, wśród których warto zwrócić uwagę na Kodeks etyki nauczycielskiej wydany w 1995 roku. Odwołuje się on bardzo wyraźnie do moralności opartej na uniwersalnych i niezmiernych wartościach. Według zapisów kodeksu „nauczyciel powinien stanowić wzór osobowości prawej i szlachetnej, wrażliwej i odpowiedzialnej, o postawie otwartej na drugiego człowieka" ${ }^{\text {. }}$. Postawa pedagoga i jego odniesienie do przekazywanych wartości odgrywa kluczową rolę w kształtowaniu postawy tolerancji, gdyż ,jedność postawy, zachowań i czynów wychowawcy - z tym, co głosi w swym pedagogicznym przesłaniu" ${ }^{58}$ stanowi warunek przyjęcia wartości przez wychowanka.

Wydaje się, że dialog to metoda udzielania wsparcia, która jest najbardziej adekwatna do zadań pomocowych. Ze swej natury jest on oparty na spotkaniu, interakcji, gotowości na rozumienie drugiego człowieka oraz dążeniu do ustalenia kompromisu prowadzącego do poznania prawdy, dobra i piękna ${ }^{59}$. Zaangażowanie w dialog wychowawczy, który respektuje różnorodność, a jednocześnie dąży do konsensusu, jest optymalnym wskazaniem dla pedagogów respektujących zasady etosu zawodowego.

55 Por. M. Jabłoński, J. Nawrocki, Kompetencje pedagogiczne nauczyciela jako podstawowa wartość w ksztattowaniu relacji między wychowankiem a wychowawca, [w:] Ewaluacja i innowacje..., dz. cyt., s. 82. Por. J. Homplewicz, Etyka..., dz. cyt., s. 201.

57 Polskie Towarzystwo Nauczycieli, Kodeks etyki nauczycielskiej (1995), Ząbki 1997, 1: Zasady ogólne etyki nauczycielskiej.

58 J. Homplewicz, Etyka..., dz. cyt., s. 173.

59 Por. M. Śnieżyński, Dialog w rodzinie, Kraków 2012, s. 24. 


\section{Wartości w pomocy medycznej}

Pomoc medyczna, rozpatrywana w kontekście wsparcia społecznego, ma wiele form. Wśród nich można wymienić: edukację prozdrowotną, doradztwo dotyczące opieki nad chorymi, profilaktykę, diagnozę, leczenie szpitalne czy rehabilitację $e^{60}$ Każda ze stosowanych form pomocy zmierza do realizacji podstawowego celu powołania lekarza, którym jest „ochrona życia i zdrowia ludzkiego, zapobieganie chorobom, leczenie chorych oraz niesienie ulgi w cierpieniu. Cele medycyny można więc określić w trzech obszarach podejmowanych działań: prewencji, terapii (w tym rehabilitacji i różnych aspektów opieki nad chorym), łagodzenia bólu, cierpienia i towarzyszenie w umieraniu ${ }^{61}$. Kodeks etyki lekarskiej podkreśla, że „najwyższym nakazem etycznym lekarza jest dobro chorego"62. Oznacza to, że działania lekarskie nie mogą naruszać dobra człowieka wspomaganego.

Normy etyczne, które podaje kodeks, mają na celu ochronę wartości, które stoją u podstaw systemów pomagania. Wartości, które bezpośrednio łączą się z pomocą medyczną, to życie i zdrowie pacjenta. Kwestia ta jest bardzo istotna, ponieważ współczesna medycyna coraz częściej staje przed dylematami związanymi z tymi podstawowymi wartościami ${ }^{63}$. Optymalna jest sytuacja, gdy „ochronie tych wartości jest poświęcone działanie wszystkich pracowników medycznych. To, co łączy i spaja wyżej wymienione zawody medyczne, jest związane z dobrem pacjenta, czyli z poszanowaniem jego godności, autonomii oraz z ochroną życia i zdrowia [...]. Dlatego tak ważne stają się właściwe

60 Por. B. Hajduk, E. Hajduk, O rodzajach, dz. cyt., s. 27-28.

61 Por. A. Muszala, Jaki jest cel medycyny? Kodeks etyki lekarskiej, „Medycyna Praktyczna" 2013 nr 10, www.mp.pl (15.07.2014).

62 Kodeks etyki lekarskiej, art. 2, www.nil.org.pl (15.07.2014).

63 Por. M. Gałuszka, Społeczne i kulturowe powinności medycyny. Tożsamość zawodowa i atrofia moralna, Wrocław 2003, s. 63. 
relacje i stosunki międzyludzkie dotyczące samych pracowników medycznych oraz chorych pacjentów" 64 .

Ochrona zdrowia i życia człowieka ma więc silne odniesienie aksjologiczne. Idea pomocy medycznej świadczonej przez lekarzy, pielęgniarki lub innych pracowników ochrony zdrowia opiera się na wartości godności osoby, miłości, empatii, autonomii i innych wartości służących dobru społeczeństwa i jednostki. Wśród nich warto zwrócić szczególną uwagę na miłość, która wyraża się poprzez troskę osób świadczących pomoc o dobro osoby wspomaganej. To ona „jest w stanie nadać też właściwy, podmiotowy i personalistyczny kształt strukturom społecznym decydującym o kształcie życia jednostek"65. Można więc przyjąć, że stanowi aksjologiczną podstawę wszelkich działań pomocowych, a zwłaszcza świadczonych wobec osób znajdujących się w trudnej sytuacji życiowej, jaką jest choroba i cierpienie. Przyjmuje wtedy formę czynnego miłosierdzia, które wzmocnione poczuciem solidarności z cierpiącym, inspiruje do podejmowania kolejnych działań poprawiających jakość życia pacjenta.

Można przyjąć, że im wyżej wartość jest postawiona w hierarchii, tym zakres jej oddziaływania jest większy, dlatego obecność miłości w założeniach działań medycznych jest szczególnie pożądana. Docenienie jej na poziomie założeń daje szansę na wdrożenie jej zasad w praktyce pomocy medycznej. Troska o dobro chorego człowieka zakłada uznanie jego godności, która wzmacnia odpowiedzialność za niego i współodczuwanie oraz kształtuje postawę świadomej obecności ${ }^{66}$. Wydaje się, że owa świadoma obecność stanowi szczególnie istotny aspekt w świadczeniu wsparcia medycznego. Zakłada nie tylko konieczność poświęcenia

\footnotetext{
64 A. Nawrocka, Etos w zawodach medycznych, Kraków 2008, s. 7.

65 J. Wróbel, Człowiek $i$ medycyna. Teologicznomoralne podstawy ingerencji medycznych, Kraków 1999, s. 209.

66 Por. U. Krzyżanowska-Łagowska, Wartości duchowe $w$ etosie pielęgniarskim. Duchowość, humanizm, profesjonalizm, holizm, Kraków 2005, s. 169-171.
} 
choremu czasu, ale również troskę o wysoką jakość wspólnie spędzonego czasu. Warunkiem osiągnięcia tej postawy jest wypracowanie umiejętności słuchania i gotowości poświęcenia swego czasu. Dzięki temu troska o chorego nabiera holistycznego charakteru i łatwiej może odpowiedzieć na potrzeby pacjenta związane zarówno z cierpieniem somatycznym, jak i duchowym.

Ochrona zdrowia jest realizowana na styku kilku newralgicznych płaszczyzn życia społecznego, stąd „spośród wszystkich grup zawodowych lekarze i pielęgniarki znajdują się na najbardziej odpowiedzialnym odcinku, w którym dzięki ich kulturze ducha załamany człowiek może odzyskać utraconą nadzieję [...]. Przedstawiciele służby zdrowia jawią się choremu jako osoby dzielące jego cierpienie i niosące pierwszy promień nadziei. Dlatego też tak ważne jest obustronne budowanie klimatu humanizmu płynącego z szacunku dla każdej osoby ludzkiej"67.

Klimat szacunku, który winien obejmować podmioty świadczące jak i odbierające pomoc, jest uwarunkowany m.in. przez wzajemne traktowanie się jako równoprawni partnerzy ${ }^{68}$. Okazywanie troski nie jest tym samym, co okazywanie litości, która zakłada wyższość osób pomagających. Tworzeniu klimatu humanizmu i szacunku nie służą również nieetyczne praktyki funkcjonujące na rynku pomocowym: „Wobec rodzącego się modelu konsumpcyjnych usług medycznych, sztuka leczenia sprowadza się do handlu na wolnym rynku, w oparciu o negocjację ceny i spełnienie wymagań kontraktu. Nie służy to budowaniu właściwych relacji na płaszczyźnie lekarz - pacjent ani poczucia bezpieczeństwa dla chorego" ${ }^{69}$.

67 J. Życiński, Godność i medycyna, Lublin 2004, s. 12-13.

68 Por. U. Krzyżanowska-Łagowska, Wartości..., dz. cyt., s. 173.

69 K. Pikor, J. Tereszkiewicz, K. Bar, Czy podjęcie pracy w zawodach medycznych wymaga powotania?, „Przegląd Urologiczny” 2012 nr 4, www.przeglad-urologiczny.pl (15.07.2015). 
Aby zachować neutralność, uszanować godność i osobistą wolność pacjenta, należy wciąż odwoływać się do wartości konstytuujących etos pracowników medycznych. Przy założeniu, że wśród fundamentalnych wartości miłość ma szczególne własności koncentrujące pozostałe z nich, można przyjąć, że katalog wartości i postaw może obejmować:

- stałość w zaufaniu, dzięki któremu możliwa jest interpersonalna relacja pacjent - lekarz oraz właściwe leczenie;

- ograniczenie swoich korzyści, gdyż chory jest podatny na zranienia i staje się zależny od potęgi lekarza i medycyny;

- intelektualną uczciwość, dzięki której pacjent zna prawdę oraz może świadomie włączyć się w proces leczenia;

- współczucie umożliwiające zrozumienie ludzkich uczuć;

- odwage w realizacji dobra pacjenta wbrew komercjalizacji, depersonalizacji i ekonomizacji medycyny;

- sprawiedliwość i roztropność w łączeniu użycia techniki z dobrem pacjenta jako osoby ${ }^{70}$.

Wydaje się, że realizacja wymienionych wartości często pozostaje w sferze działań postulowanych, a proces ich wdrożenia napotyka wiele trudności. Niemniej istotne jest, by podejmować problematykę aksjologiczną w obszarze wsparcia, które wymaga szczególnej miłości i wynikającej $\mathrm{z}$ niej troski.

\section{Pomoc prawna a wartości}

Zakres udzielania pomocy prawnej jest szeroki. Mogą to być porady prawne, redagowanie dokumentów i pism,

\footnotetext{
70 Por. tamże.
} 
badanie zgodności normy z normą wyższego rzędu, ukazywanie konsekwencji społecznych obowiązujących norm prawnych itp. ${ }^{71}$. Szeroki zakres działań podejmowanych przez prawników sprawia, że konieczne jest wyspecjalizowanie się w świadczeniu wsparcia. Ma ono służyć tworzeniu ładu społecznego poprzez zachowanie jego prawnych zasad, a w konsekwencji chronić jednostkę przed bezradnością.

W sektorze wsparcia społecznego pomocy prawnej udzielają eksperci, doradcy i konsultanci. Duże zapotrzebowanie na pomoc prawną świadczy m.in. o złożoności zgłaszanych problemów, niekiedy o niewydolności prawodawstwa czy o niewystarczającym poziomie zaufania społeczeństwa do ładu tworzonego na podstawie norm moralnych i społecznych: „Spór o prawo, o to, co się komu należy, przenika coraz silniej wszystkie sfery życia, w których wcześniej nikomu nie przychodziło na myśl stawianie pytań o prawo"72.

Spór o prawo, o którym pisał Marek Safjan, dotyczy nie tylko kwestii spójności i wydolności prawa, ale sięga także do jego fundamentów. Odwołanie do źródeł norm pozwala na lepsze zrozumienie ich znaczenia i głębiej uzasadnia nakaz ich stosowania. Kwestia ta ma niebagatelne znaczenie, gdyż pozwala odpowiedzieć na pytanie: „Jakim celom prawo ma służyć i kto określa wartości, które prawo ma chronić?"73. W dyskusji nad aksjologicznymi uwarunkowaniami norm prawnych coraz częściej rozbrzmiewają głosy podważające zasadność odwoływania się do wartości powszechnie przyjętych, zwłaszcza jeśli mają one charakter obiektywny i niezmienny. Warto zaznaczyć, iż

71 Por. B. Hajduk, E. Hajduk, O rodzajach..., dz. cyt., s. 32-33.

72 M. Safjan, Rola prawnika we wspótczesnym świecie, Lublin 2004, s. 23.

73 W. Łączkowski, Prawnik katolicki a problemy wartości prawa, [w:] Prawnik katolicki a wartości prawa, Kraków 1999, s. 67. 
zredukowanie prawa do ustaleń zależnych jedynie od demokratycznie podjętych decyzji pozbawia je fundamentalnych cech, co staje się szczególnie dotkliwie odczuwane w sektorze wsparcia społecznego. Publiczne odwoływanie się do osądu sumienia nierzadko wzbudza niechęć: „Sprzeciw sumienia zakłóca bowiem funkcjonowanie instytucji państwowych. Stąd państwo narzuca wymóg neutralności aksjologicznej, moralnej i religijnej w urzędach państwowych, w pracy, w działalności społecznej"74.

Dla zrównoważenia tych tendencji należy wskazać podstawowe wartości, które winny być chronione przez normy prawne. Z pomocą w realizacji tego zadania przychodzi aksjologia prawa, która prowadzi badania „pozwalające zrekonstruować właściwości wartości będących podstawami aksjologicznymi prawa. Ogólną typologię takich wartości można sporządzić, posługując się kryterium zamiaru realizacyjnego lub jego braku u podmiotu relacji wartościującej"75. Biorąc pod uwagę to kryterium, można przyjąć, że istnieją wartości zasadnicze i instrumentalne. Te ostatnie są wykorzystywane dla osiągnięcia konkretnych korzyści, natomiast wartości zasadnicze nie są odczuwane „dla nich samych" i stanowią podstawę systemu prawnego ${ }^{76}$. Wśród nich poczesne miejsce zajmuje sprawiedliwość, która określa sens i cel działania systemu prawnego.

Sprawiedliwość jest kojarzona z porządkiem jurydycznym, a gdy jej znaczenie zostanie poszerzone o odniesienie moralne, jest ona wypełnieniem reguły: „Oddać każdemu, co mu się należy"77. W działaniach pomocowych sprawiedliwość jest wartością najbardziej pożądaną, gdyż

74 T. Biesaga, Zagrożenie sumienia $w$ demokracji, [w:] Prawa człowieka $i$ świat wartości, red. R. Moni, A. Kobyliński, Warszawa 2011, s. 39.

75 K. Pałecki, Aksjologia prawa, [w:] Leksykon socjologii prawa, red. A. Kociołek-Pęksa, M. Stępień, Warszawa 2013, s. 5.

76 Por. tamże, s. 7.

77 W. Świerzawski, Etos prawnika, Sandomierz 1996, s. 11-12. 
jej przywrócenie ma na celu wszystkie działania na rzecz pokrzywdzonych.

Sprawiedliwość w obszarze wsparcia społecznego wyraża się m.in. poprzez zastosowanie zasad etyki prawniczej. Wśród nich można wymienić:

- zaufanie i lojalność, która polega na budowaniu zaufania klienta do prawnika oraz jego lojalności i generuje konsekwentną pomoc w realizacji interesów klienta, a co za tym idzie ochronę tajemnicy zawodowej i unikanie konfliktu interesów;

- integralność moralną oznaczającą obowiązek zachowania moralnej spójności w sądach i czynach i będącą postulatem stosowania jednolitych standardów w ocenach moralnych czynów swoich i innych ludzi;

- niezawisłość, czyli nieuleganie przez sędziego żadnym płynącym z zewnątrz wpływom i naciskom, które mogłyby zmienić treść orzeczenia;

- niezależność oznaczającą zespół gwarancji, w które powinien być wyposażony prawnik, aby móc skutecznie opierać się wpływom i naciskom;

- bezstronność realizowaną w kontekście osądu i oznaczającą sprawiedliwe wymierzanie wyroku w oparciu o uczciwość i godność;

- staranność i odpowiedzialność w działaniu, które zobowiązuja prawnika do rzetelnego i odpowiedzialnego prowadzenia sprawy czy udzielania porad, gdyż od miary jego staranności i odpowiedzialności zależy bezstronne i sprawiedliwe rozstrzygnięcie sprawy ${ }^{78}$.

Sprawiedliwość i uczciwość obecne w realizacji wsparcia społecznego dają ludziom potrzebującym nadzieję na rozwiązanie ich problemów. Przekonanie, że osoby, do których zwracają się o pomoc, pracują w oparciu o zasadę

78 Por. P. Skuczyński, Pojęcia i zasady etyki prawniczej. Wprowadzenie, [w:] Etyka zawodów prawniczych. Etyka prawnicza, red. H. Izdebski i P. Skuczyński, Warszawa 2006, s. 93-94. 
prawdy i według wcześniej wymienionych standardów etycznych, wzbudza zaufanie. Aksjologiczne uwarunkowania pomocy prawnej wiążą się z koniecznością sprostania trudnym niekiedy wyzwaniom o charakterze etycznym, ale podjęcie tego trudu owocuje w postaci rzetelnie udzielonych porad oraz budowania prawdziwego społecznego zaufania wokół zawodu prawnika.

\section{Zakończenie}

Teoretyczne rozważania na temat związku wartości z działaniami pomocowymi kryją w sobie niebezpieczeństwo popadnięcia w moralizatorski ton bądź zatrzymania się na poziomie postulatów trudnych do spełnienia. Zamierzeniem dokonanych analiz nie było szczegółowe opracowanie zagadnienia aksjologicznych uwarunkowań procesu wsparcia społecznego, jego ocena czy stworzenie programu naprawczego. Chodziło raczej o zwrócenie uwagi na fakt, że każde spotkanie człowieka z człowiekiem, a szczególnie to odbywające się w trudnej sytuacji życiowej przynajmniej jednego z nich, ma głębokie znaczenie aksjologiczne. Ze względu na swą delikatność wartości domagają się ochrony w postaci norm etycznych, które winny być respektowane w działaniach pomocowych.

Przedstawienie zarysu aksjologicznych odniesień obecnych w pracy socjalnej, pomocy pedagogicznej, medycznej i prawnej pokazało, że różne działania nawiązują do tych samych wartości, u podstaw których znajduje się godność człowieka. Chociaż aksjologiczne akcenty rozkładają się różnie dla każdego obszaru pomocy, wszystkie mają istotne znaczenie dla osiągnięcia optymalnego poziomu pomagania. W analizach zwrócono uwagę na etyczne konsekwencje przyjętych wartości, co dokonało się poprzez odwołanie do zasad etyki zawodowej, kodeksów etycznych czy postulatów moralnych. Wynika z nich, że na poziomie 
normatywnym wartości są głęboko osadzone w działaniach społecznych. Doświadczenie pokazuje, że istotnym problemem jest ich transfer do codzienności.

Pomimo tych braków warto zauważyć, iż perspektywy rozwoju obszaru wsparcia społecznego są bardzo duże. W związku z tym konieczne wydaje się, by refleksja o podłożu aksjologicznym nieustannie towarzyszyła dokonującym się przemianom. Chociaż w dzisiejszym ferworze wokół działań pomocowych głosy przypominające o wartościach pobrzmiewają nader nieśmiało, ważne jest, by nie ustawały. Ich wzmacnianie daje nadzieję na wsparcie coraz bardziej wierne człowiekowi, jego godności i naturze.

\section{Bibliografia}

Badura-Madej W., Podstawowe pojęcia teorii kryzysu i interwencji kryzysowej, [w:] Wybrane zagadnienia interwencji kryzysowej. Poradnik dla pracowników socjalnych, red. W. Badura-Madej, Warszawa 1996.

Bera R., Aksjologiczne aspekty pracy socjalnej, [w:] Przestrzenie dziatania $w$ pracy socjalnej $w$ wymiarze etyczno-prakseologicznym, red. M. Czechowska-Bieluga, A. Kanios, L. Adamowska, Kraków 2010.

Bielecka E., Tradycyjne $i$ innowacyjne formy interwencji spotecznej, [w:] Zagrożona młodość. Innowacyjne formy interwencji społecznej, red. E. Bielecka, Warszawa 2010.

Biernat T., Duchowy wymiar pracy socjalnej. Potencjat wiary, nadziei i miłości, „Praca Socjalna” 2011 nr 6, s. 3-14.

Biesaga T., Zagrożenie sumienia $w$ demokracji, [w:] Prawa człowieka i świat wartości, red. R. Moni, A. Kobyliński, Warszawa 2011.

Chałas K., Wychowanie ku wartościom. Elementy teorii i praktyki, t. I, Lublin-Kielce 2006.

Czechowska-Bieluga M., Preferencja wartości a rozwój (wybrane zagadnienia), „Praca Socjalna” 2007 nr 2, s. 3-13.

Galarowicz J., Nowy elementarz etyczny, Kraków 2011. 
Gałuszka M., Społeczne i kulturowe powinności medycyny. Tożsamość zawodowa i atrofia moralna, Wrocław 2003.

Garvin C. D., Seabury B. A., Dziatania interpersonalne w pracy socjalnej. Procesy i procedury, tł. J. Banasiak, Warszawa 1996.

Gerrig R. J., Zimbardo P. G., Psychologia i życie. Wydanie nowe, Warszawa 2011.

Godawa G., Nauczyciel dzieci - wychowawca rodziców. Oddziatywanie wychowawcze kompetentnego nauczyciela na sfere duchowa rodziców uczniów (na podstawie badań rodziców w krakowskich szkołach), [w:] Ewaluacja $i$ innowacje $w$ edukacji. Kompetencje i odpowiedzialność nauczyciela, red. J. Grzesiak, Kalisz-Kosza$\operatorname{lin} 2010$.

Godawa G., Odpowiedzialność nauczyciela za niewypowiedziane słowa, czyli o zaniedbaniu pedagogicznym w szkole, „Studia Socialia Cracoviensia" 2010 nr 3, s. 93-103.

Hajduk B., Hajduk E., O rodzajach pomocy, Kraków 2006.

Homplewicz J., Etyka pedagogiczna, Kraków 2000.

Jabłoński M., Nawrocki J., Kompetencje pedagogiczna nauczyciela jako podstawowa wartość $w$ ksztattowaniu relacji między wychowankiem a wychowawca, [w:] Ewaluacja i innowacje w edukacji. Kompetencje i odpowiedzialność nauczyciela, red. J. Grzesiak, Kalisz-Koszalin 2010.

Kanios A., Wokót profesjonalizmu pracowników socjalnych - analiza badawcza, „Praca Socjalna” 2012 nr 3, s. 81-93.

Kanios A., Czechowska-Bieluga M., Preferencyjne wartości a wypalenie zawodowe osób profesjonalnie świadczacych pomoc, „Praca Socjalna" $2010 \mathrm{nr}$ 6, s. 56-67.

Kawula S., Pedagogizacja rodziców, [w:] Encyklopedia pedagogiczna, red. W. Pomykało, Warszawa 1993, s. 581-585.

Kenrick D. T., Neuberg S. L., Cialdini R. B., Psychologia społeczna. Rozwiane tajemnice, Gdańsk 2002.

Kluz M., O realizacje wartości moralnych $w$ dziataniu pracowników socjalnych, „Praca Socjalna” 2012 nr 3, s. 26-39.

Kodeks etyki lekarskiej, www.nil.org.pl (15.07.2014).

Kodeks etyczny Polskiego Towarzystwa Pracowników Socjalnych (1994), www.mgopsmiroslawiec.bipstrona.pl (13.07.2014). 
Krzyżanowska-Łagowska U., Wartości duchowe w etosie pielęgniarskim. Duchowość, humanizm, profesjonalizm, holizm, Kraków 2005.

Kubacka-Jasiecka D., Interwencja kryzysowa. Pomoc w kryzysach psychologicznych, Warszawa 2010.

Kuczkowska-Krukowska A., Istota wspomagania społecznego - przegląd wybranych stanowisk, „Wychowanie na co Dzień” 2006 nr 6, s. $16-20$.

Łączkowski W., Prawnik katolicki a problemy wartości prawa, [w:] Prawnik katolicki a wartości prawa, Kraków 1999.

Lichnerowicz E., Praca socjalna $w$ organizacjach pozarzadowych i instytucjach publicznych - perspektywa pracownika socjalnego, „Trzeci Sektor” numer specjalny 2012/2013, s. 82-89.

Łuczyńska M., O odpowiedzialności etycznej pracownika socjalnego, [w:] T. Kaźmierczak, M. Łuczyńska, Wprowadzenie do pomocy społecznej, Katowice 1998.

Marszałek L., Systemy wsparcia społecznego w rehabilitacji osób niepetnosprawnych, „Seminare” 2009 t. 26, s. 201-213.

Muszala A., Jaki jest cel medycyny? Kodeks etyki lekarskiej, „Medycyna Praktyczna” 2013 nr 10, www.mp.pl (15.07.2014).

Nawrocka A., Etos w zawodach medycznych, Kraków 2008.

Pałecki K., Aksjologia prawa, [w:] Leksykon socjologii prawa, red. A. Kociołek-Pęksa, M. Stępień, Warszawa 2013, s. 1-7.

Pikor K., Tereszkiewicz J., Bar K., Czy podjęcie pracy w zawodach medycznych wymaga powołania?, „Przegląd Urologiczny” $2012 \mathrm{nr} 4$, www.przeglad-urologiczny.pl (15.07.2015).

Polskie Towarzystwo Nauczycieli, Kodeks etyki nauczycielskiej (1995), Ząbki 1997.

Podrez E., Tolerancja - problemy i dylematy nie tylko moralnej natury, [w:] Tolerancja i wielokulturowość. Wyzwania XXI wieku, red.

A. Borowiak, P. Szarota, Warszawa 2004.

Ryczan K., Wychowanie ku wartościom, [w:] Na przełomie stuleci. Naród - Kościót - państwo w XIX i XX wieku, red. M. Piotrowski, Lublin 1997.

Safjan M., Rola prawnika we wspótczesnym świecie, Lublin 2004.

Sęk H., Wprowadzenie do psychologii klinicznej, Warszawa 2007. 
Sęk H., Cieślak R., Wsparcie społeczne - sposoby definiowania, rodzaje i źródta wsparcia, wybrane koncepcje teoretyczne, [w:] Wsparcie społeczne, stres $i$ zdrowie, red. H. Sęk, R. Cieślak, Warszawa 2004.

Sobór Watykański II, Konstytucja duszpasterska o Kościele w świecie współczesnym Gaudium et spes, 1965.

Skuczyński P., Pojęcia i zasady etyki prawniczej. Wprowadzenie, [w:] Etyka zawodów prawniczych. Etyka prawnicza, red. H. Izdebski, P. Skuczyński, Warszawa 2006, s. 93-98.

Ślipko T., Etyka, [w:] Stownik społeczny, red. B. Szlachta, Kraków 2004, s. 248-279.

Tischner J., Myślenie według wartości, Kraków 1994.

Śnieżyński M., Dialog w rodzinie, Kraków 2012.

Świerzawski W., Etos prawnika, Sandomierz 1996.

Walden-Gałuszko de K., Problemy psychiczne, duchowe $i$ etyczne, [w:] Pielegniarstwo w opiece hospicyjnej, red. K. de Walden-Gałuszko, A. Kaptacz, Warszawa 2008.

Winiarski M., Wsparcie społeczne, [w:] Encyklopedia pedagogiczna XXI wieku, red. T. Pilch, t. VII, Warszawa 2008, s. 267-275.

Włodarczyk D., Wsparcie społeczne a radzenie sobie ze stresem u chorych po zawale serca, „Przegląd Psychologiczny” 1999 t. 42 nr 4, s. $95-113$.

Wróbel J., Człowiek i medycyna. Teologicznomoralne podstawy ingerencji medycznych, Kraków 1999.

Zowczak J., Etos nauczycieli w warunkach polskiej transformacji, Warszawa 2008.

Życiński J., Godność i medycyna, Lublin 2004.

\section{Streszczenie}

Pomoc drugiemu człowiekowi jest jedną z postaw prospołecznych cieszących się powszechnym uznaniem. Świadczenie pomocy nie ma jedynie wymiaru pragmatycznego, a skuteczność podejmowanych działań nie zależy jedynie od wielości posiadanych środków czy zastosowanej metodyki 
działań pomocowych. Idea wsparcia sięga znacznie głębiej, gdyż pomoc udzielana człowiekowi domaga się podjęcia działań na miarę jego godności. Problematyka aksjologiczna jest więc związana z wieloma obszarami wsparcia społecznego. Wartości, które winny stanowić fundament działań pomocowych, są jednak często pomijane. $Z$ tego względu potrzebny jest wysiłek ciągłego powracania do nich i odkrywania ich wpływu na jakość wsparcia społecznego.

Analiza literatury przedmiotu ukazała podstawowe wartości związane z pomaganiem. Odniesienie ich do wybranych obszarów wsparcia pozwoliło na zaprezentowanie zakresu ich oddziaływań zwłaszcza w przestrzeni pracy socjalnej, pomocy pedagogicznej, medycznej i prawnej. Istotnym efektem dokonanych analiz jest zwrócenie uwagi na etyczne aspekty omawianych zagadnień. Dzięki tym odniesieniom wartości są chronione i eksponowane, a także cieszą się lepszą percepcją. Podkreślenie roli etyki zawodowej w działaniach pomocowych jest konsekwencją uzyskanych wniosków.

Słowa kluczowe: aksjologia, wsparcie społeczne, praca socjalna, pomoc pedagogiczna, wsparcie medyczne, wsparcie prawne

\section{Summary}

\section{Axiological principles of social support}

Helping others is one of the social attitudes which are widely appreciated. It does not only have a pragmatic dimension and its effectiveness does not depend solely on the variety of resources or methodology of helping activities. The idea of support is much deeper because man's dignity needs to be taken into consideration while helping others. The issue of axiology is therefore related to a lot of aspects of social support. 
Values which should form the basis of helping activities are often disregarded. Hence, it is necessary to make an effort to come back to them and discover their influence on the quality of social support.

Analysis of source literature presented basic values connected with giving help. Referring them to the chosen aspects of support made it possible to define the scope of their influence on social work as well as on pedagogical, medical and legal help. Putting emphasis on the ethical aspects of the issue is a significant effect of the analysis. Thanks to these references the values can be saved, presented and perceived in a better way. Stressing the role of work ethics in helping activities is a consequence of conclusions which were reached.

Keywords: axiology, social support, social work, pedagogical help, medical support, legal support

ks. Grzegorz Godawa, Aksjologiczne podstawy wsparcia spotecznego, [w:] Pedagogiczne konteksty spotecznego wsparcia rodziny, red. ks. Grzegorz Godawa, Kraków 2015, s. 40-76. 